\title{
Phytosociology, diversity and floristic similarity of a Cerrado fragment on Southern Ceará state, Brazilian Semiarid
}

\author{
Fitossociologia, diversidade e similaridade florística de um fragmento de \\ Cerrado no Sul do Ceará, Semiárido Brasileiro
}

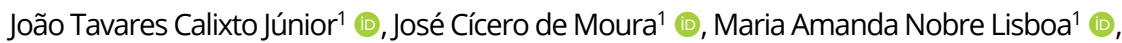

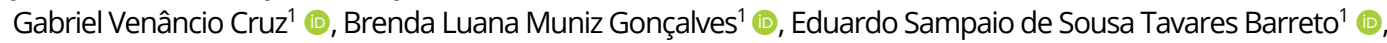
Luiz Marivando Barros ${ }^{1}$ (D), Marcos Antônio Drumond² (D), Ana Cleide Alcântara Morais Mendonça' (D), Leonardo Silvestre Gomes Rocha ${ }^{3}$ (D), Maria Arlene Pessoa da Silva' ${ }^{1}$, Luciana Silva Cordeiro' ${ }^{1}$ (])

${ }^{1}$ Universidade Regional do Cariri - URCA, Crato, CE, Brasil

${ }^{2}$ Empresa Brasileira de Pesquisa Agropecuária - EMBRAPA SEMIÁRIDO, Petrolina, PE, Brasil

${ }^{3}$ Universidade Federal Rural do Rio de Janeiro - UFRRJ, Rio de Janeiro, RJ, Brasil

How to cite: Calixto Júnior, J. T., Moura, J. C., Lisboa, M. A. N., Cruz, G. V., Gonçalves, B. L. M., Barreto, E. S. S. T., Barros, L. M., Drumond, M. A., Mendonça, A. C. A. M., Rocha, L. S. G., Silva, M. A. P., Cordeiro, L. S. (2021).

Phytosociology, diversity and floristic similarity of a Cerrado fragment on Southern Ceará state, Brazilian Semiarid. Scientia Forestalis, 49(130), e3459. https://doi.org/10.18671/scifor.v49n130.01

\begin{abstract}
There is a lack of studies on phytosociology of Cerrado fragments within the Caatinga biome, located in the Southern region of Ceará State, associated to the Brazilian Crystalline Shield geological formation. Thus, contributing to the diagnosis and knowledge of this plant community, a survey on the general flora and especially the structure of arboreal vegetation was made. Every individual with SND $\geq 3 \mathrm{~cm}$ (total height), within 12 parcels with $12 \times 30 \mathrm{~m}$ ( $0.432 \mathrm{ha})$ of area was sampled. The floristic similarity was calculated by the Jaccard index, in comparison with ten other Brazilian Cerrado areas. Fourty-six species distributed in 22 families were found, comprising a total of 906 individuals, with $A D=2,097.22$ ind.ha-1. The highest abundance was found within families Fabaceae (20.31\%) and Vochysiaceae (19.98\%). Qualea parviflora, Annona leptopetala, Hymenaea stignocarpa and Callisthene fasciculata had the highest IVI index species. The calculated biodiversity indexes were: alpha diversity of Shannon $(H)=3.8$ and equitability of Pielou $(/)=0.83$. The results obtained show the area as a vegetation relict, under threat due to the penetration of Caatinga species, climatic changes, insufficient conservation efforts and fast anthropic deforestation. As a result, this relict area tends to shrink to a fragment much smaller than it was in the past.
\end{abstract}

Keywords: Cerrado spots; Lavras da Mangabeira; Serra do Boqueirão.

\section{Resumo}

No Sul do Ceará há carência de estudos de fitossociologia em fragmentos de Cerrado em meio à Caatinga do cristalino. Assim, visando contribuir para o reconhecimento e diagnóstico dessa vegetação, realizouse levantamento da flora e estrutura da vegetação arbórea em mancha localizada em solos profundos e relevo tabular na Serra do Boqueirão (289 m Alt.), em Lavras da Mangabeira (6²72'24" S e 38 $97^{\prime} 73^{\prime \prime}$ W). Em 12 parcelas de $12 \times 30 \mathrm{~m}(0,432 \mathrm{ha})$ foram inventariados todos os indivíduos com DNS $\geq 3 \mathrm{~cm}$, observando-se altura total. Para observar a similaridade florística comparou-se, pelo método de Jaccard, outras 10 áreas de Cerrado em diferentes regiões do País. Foram encontradas 46 espécies distribuídas em 22 famílias, num total de 906 indivíduos, com DA=2.097,22 ind.ha-1 . As famílias Fabaceae (20,31\%) e Vochysiaceae $(19,98 \%)$ apresentaram maior número de indivíduos. Qualea parviflora, Annona leptopetala, Hymenaea stignocarpa, Callisthene fasciculata e Anacardium occidentale foram as espécies de maior IVI. O

Financial support: Cearense Foundation for Support for Scientific and Technological Development (FUNCAP) -BP3-0139-00197.01.00/18; National Council for Scientific and Technological Development (CNPq) and the Regional University of Cariri (URCA).

Conflict of interest: Nothing to declare.

Correspondig author: joaojrbio@gmail.com

Received: 30 August 2019.

Accepted: 22 January 2020

Editor: Paulo Henrique Müller Silva.

(c) (i) This is an Open Access article distributed under the terms of the Creative Commons Attribution License, which permits unrestricted use,

cc) distribution, and reproduction in any medium, provided the original work is properly cited. 
índice de Shannon $\left(H^{\prime}\right)$ para a diversidade alfa foi 3,18, a equabilidade de Pielou ( $/$ ) foi 0,83 e o índice de Simpson (C) foi 0,05. A diversidade beta entre o local estudado e outras áreas de Cerrado (central e disjuntos) foi considerada alta e a estatística apontou maior similaridade com Cerrado sensu stricto de tabuleiro litorâneo. Por fim, os resultados permitem caracterizar a área como relíquia vegetacional, que pela visível penetração da flora da Caatinga, aliada às modificações climáticas, ao desinteresse na preservação e aceleração do desmatamento pelo antropismo, tende a diminuir, restringindo-se à área bem menos ampla do que a que abrangeu a região no passado.

Palavras-chave: Manchas de Cerrado; Lavras da Mangabeira; Serra do Boqueirão.

\section{INTRODUCTION}

The Brazilian Cerrado is considered to host the highest biodiversity savanna environment of the world (Silveira, 2010), with more than 11,000 indigenous plant species cataloged (Klink \& Machado, 2005), covering an estimated range of 2,036,448 $\mathrm{Km}^{2}$ (ca. 22\%) of the Brazilian territory (Instituto Brasileiro de Geografia e Estatistica, 2004).

The vegetation of the Cerrado biome comprises phyto-physiognomies including forest, savanna and grassland formations, "forest" being defined as an area with dominance of arboreal species (Ribeiro \& Walter, 1998; Tavares, 2017).

The soil is mostly dystrophic, with a low $\mathrm{pH}$ and low concentration of available calcium and magnesium and a high concentration of interchangeable aluminum (Lopes \& Cox, 1977; Neri et al., 2007). The soil characteristics, such as depth, fertility and draining capacity influence the phyto-physiognomies as much as the anthropic action does (Pivello \& Coutinho, 1996; Neri et al., 2007).

Ceará state has $57 \%$ of its territory covered by forest-ranked formations $(8,500,000$ ha), the Caatinga being its main biome, comprising $88 \%$ of the plant cover. The Cerrado covers a much smaller area (0.4\%) of the state (Brasil, 2016).

Freire (2007) conceptualizes enclaves as landscapes that differ in biotic configuration from the surrounding environment, as a result of the action of natural factors, mostly biogeographic, through geological time.

One of the many explanatory hypotheses for the presence of Cerrado enclaves in other biomes as the Amazonian and Atlantic rainforests, Caatinga (Brazilian semiarid) and coniferous forests in Southern Brazil is the Quaternary Refuge Hypothesis, which explains the expansion/retraction events of forests and arid environments through the rapid climatic variations of the Quaternary Period (Ab'Saber, 1963; Cole, 1986; Carneiro-Filho, 1993; Santos et al., 2015).

The Southern Ceará state enclaves were first identified by Figueiredo \& Fernandes (1987) and are restricted to small sedimentary reliefs located in the municipalities of Lavras da Mangabeira, Aurora, Granjeiro, Várzea Alegre, Farias Brito, Cedro, Jucás and at the top of the Chapada do Araripe (Figueiredo, 1997; Moro et al., 2015; Nepomuceno, 2016).

According to Figueiredo \& Fernandes (1987), the soil in those areas is deep (ca. $2 \mathrm{~m}$ ), red with a well-defined tone in the subsurface horizons, well-drained, being classified as podzol, which is present in the region along with other types as the noncalcic Bruno.

The execution of conservation of the biodiversity projects and sustainable management plans is only possible when the vegetation, its limitations and resilience capacity of the area of interest are properly known (Ferraz et al., 2013). Xavier (2009) emphasizes that phytosociology and floristics studies are important contributions to the knowledge of forest formations, as they display a survey on the species richness and heterogeneity of the sampled areas. For Tavares (2017), the floristics and phytosociology knowledge of forests are essential for the conservation of those formations, especially for conservation efforts, a major concern in Brazil, due to the high level of anthropic perturbations and a progressive weakening of the environmental public policies.

In this sense, this study aims in an analysis of the aspects of floristic composition, diversity and phytosociology of a Cerrado fragment at the Serra do Boqueirão, Lavras da Mangabeira municipality, Ceará state, Brazil. This is the first effort in studying the descriptive, structural and similarity aspects on the regional flora. This contribution is also highly relevant because 
of the invasion of the Cerrado fragments by the typical Brazilian semiarid vegetation, the Caatinga. As observed in this spot, this is mostly caused by topographic degradation, climate change and anthropic action due to agriculture, cattle ranching and construction industries, as well as lack of interest from the government in environment conservation and a weakening of environmental policy. As a result, the Cerrado fragments are being highly supressed and occupy an area that is much smaller than it was in the past.

\section{MATERIAL AND METHODS}

\section{Area of Study}

Serra do Boqueirão is located at the municipality of Lavras da Mangabeira, $\left(6^{\circ} 72^{\prime} 24^{\prime \prime} \mathrm{S}\right.$; $38^{\circ} 97^{\prime} 73^{\prime \prime}$ W) (Figure 1), at an elevation from 282 to $401 \mathrm{~m}$ above sea level. This municipality belongs to the semiarid portion of Northeastern Brazil, officialy designated as the Lavras da Mangabeira microregion and Southern-Central Ceará mesoregion (Instituto Brasileiro de Geografia e Estatistica, 2010). The local site on study lies near the Lavras da Mangabeira sedimentary basin, a set of three small basins covering circa $60,27 \mathrm{~km}^{2}$ of a private property, surprisingly well-preserved, without any agricultural or ranching activity. The climate is defined as Warm Tropical Semiarid (Aw), according to the Köppen classification, with two well-defined seasons (dry winters and humid summers), despite the transitory nature of the semiarid climate on Northeastern Brazil (BSh). The average annual pluviosity is $908.9 \mathrm{~mm}$ (Fundação Cearense de Meteorologia e Recursos Hídricos, 2019), the rain season being from January to April. The average annual temperature is $26.8^{\circ} \mathrm{C}$ (Instituto Nacional de Pesquisas Espaciais, 2019).

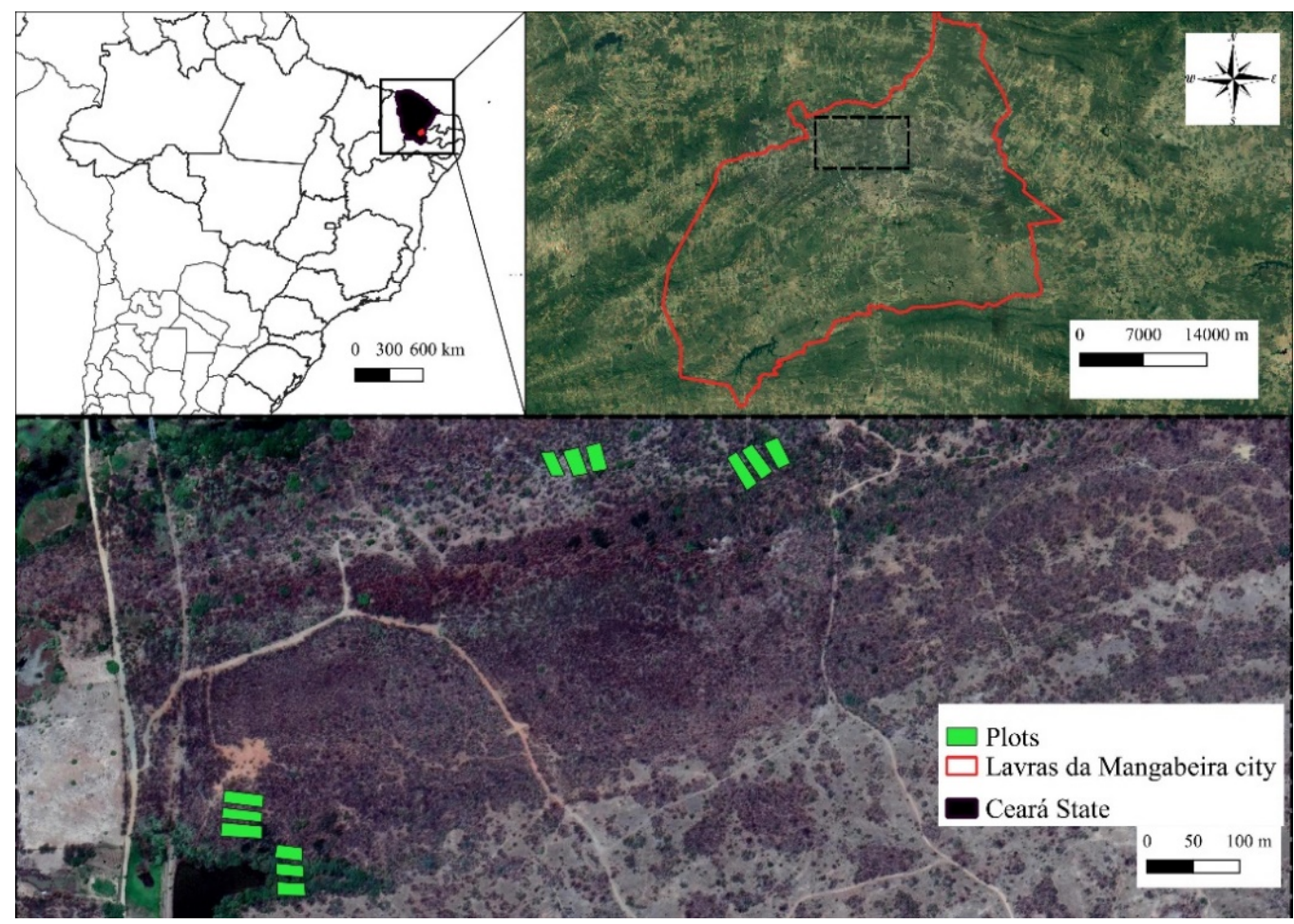

Figure 1: Geographic location of Serra do Boqueirão, Lavras da Mangabeira, Southern Ceará.

The region is intensely faulted, with the fault lines converging in a West-East direction, joining the Patos fault lining in Paraíba State. The local site of study lies between the Várzea Alegre, Granjeiro and Cuncas faults. The relief consists mainly of desiccated structural crystalline surfaces, with elongated dales and interfluves. The highly desiccated interfluves bear narrow horizontal surfaces with parallel grooves generally running along the fractures of the slopes (Figueiredo \& Fernandes, 1987). 


\section{Sample Sufficiency}

To test the sufficiency of the samples, the REGRELRP procedure on the SAEG software version 9,1 (SAEG, 2007) was used, as in Calixto Júnior \& Drumond (2011), following the sense of "species/area curve".

The sample precision was also tested by the standard error method. The coverage of this sample was observed by the calculation of the confidence interval for the density and dominance parameters, with an error limit from 10 to $95 \%$ of probability, according to Felfili \& Rezende (2003).

\section{Data collection and treatment}

A forest inventory was made to characterize the Cerrado vegetation, using the parcel methodology as proposed by Mueller-Dumbois \& Ellenberg (1974): twelve parcels with $360 \mathrm{~m}^{2}$ $(12 \mathrm{~m} \times 30 \mathrm{~m})$ of area were systematically established, totalizing 0.432 ha of area covered.

Every living individual with a DNS ( $30 \mathrm{~cm}$-height from soil) $\geq 3 \mathrm{~cm}$ was measured, as well as the total height. The measure of DNS was made with a caliper and for the total height, a graduated telescopic rod, according to Ferraz et al. (2013). In case of secondary shoots, the one with the largest diameter was measured and if it conformed to the inclusion criterions; that one and the other shoots were included, as suggested by Rodal (1992).

The botanical determination of the material was made using floral and vegetative morphological characters and by comparison with catalogued preserved specimens housed at the following botanical collections: Herbário Caririense Dárdano de Andrade-Lima, Universidade Regional do Cariri (HCDAL-URCA) and Herbário Prisco Bezerra, Universidade Federal do Ceará (EAC-UFC). Specialists and literature were also consulted for determination. The classification was based on APG IV (Angiosperm Phylogeny Group, 2016) and the taxon orthography was based on the databanks of the Missouri Botanical Garden (2019) and Flora do Brasil 2020 (2019).

\section{Phytosociological Analysis}

The phytosociological parameters were calculated with the Fitopac version 2.1.2 (Sheperd, 2010) software. The general parameters of the plant community, such as: total density, basal area, heights and diameters; and species-related parameters: absolute density $(A D)$, relative density (RD), absolute frequency (AF), relative frequency (RF), absolute dominance (ADo), relative dominance (RDo), cover value index (CVI) and importance value index (IVI) were analyzed.

For the analysis of the alpha-diversity, related to the abundance and number of the species of the community, the following indexes were used: diversity of Shannon-Weaver $\left(\mathrm{H}^{\prime}\right)$ (on Neperian base), concentration of Simpson (C) and equitability of Pielou (V), allowing the representation of the uniformity of the distribution of the individuals among every species (Magurran, 1988).

\section{Similarity analysis}

To identify the floristic similarity between the studied area and other surveys in different Cerrado areas (either disjunct or Central Cerrado) an absence/presence matrix of the species cited in ten other surveys made in eight Brazilian states was compared: Saporetti-Junior et al. (2003), Abaeté-MG; Silva-Neto et al. (2016), Dueré-TO; Assunção \& Felfili (2004), APA do Paranoá-DF; Finger \& Finger (2015), Chapada dos Guimarães and Baixada Cuiabana-MT; Moro et al. (2011), Fortaleza-CE; Medeiros et al. (2008), Carolina-MA; Oliveira et al. (2015), Jaborandi-BA; Imaña-Encinas et al. (2007), EcoMuseu do Cerrado, Pirinópolis-GO; Costa \& Araújo (2007), Chapada do Araripe, Barbalha-CE and Neri et al. (2007), Rio Jequitinhonha basin-MG.

All synonymy was eliminated using the software of the Royal Botanical Garden Species Index. The comparison between areas was conducted using the Jaccard similarity index (/), 
which expresses the similarity between areas based on the number of shared species. The resulting floristic similarity matrix was used for a cluster analysis by the UPGMA method, generating a dendrogram (Sneath \& Sokal, 1973), using Euclidian distance as dissimilarity measure, with the PAST version 3.23 (Hammer et al., 2011) software.

\section{RESULTS AND DISCUSSION}

\section{Sample Sufficiency}

In the determination of sample sufficiency by linear regression with plateau response (Figure 2), the minimum number sampling points and the intersection points between the crescent slope and the plateau were considered. The intersection was obtained from the ninth parcel $\left(3,240 \mathrm{~m}^{2}\right.$ of sampled area), with $78 \%$ of the species sampled, and no new registers of species were obtained in the latest three parcels, thus considering the sampling effort sufficient for the area.

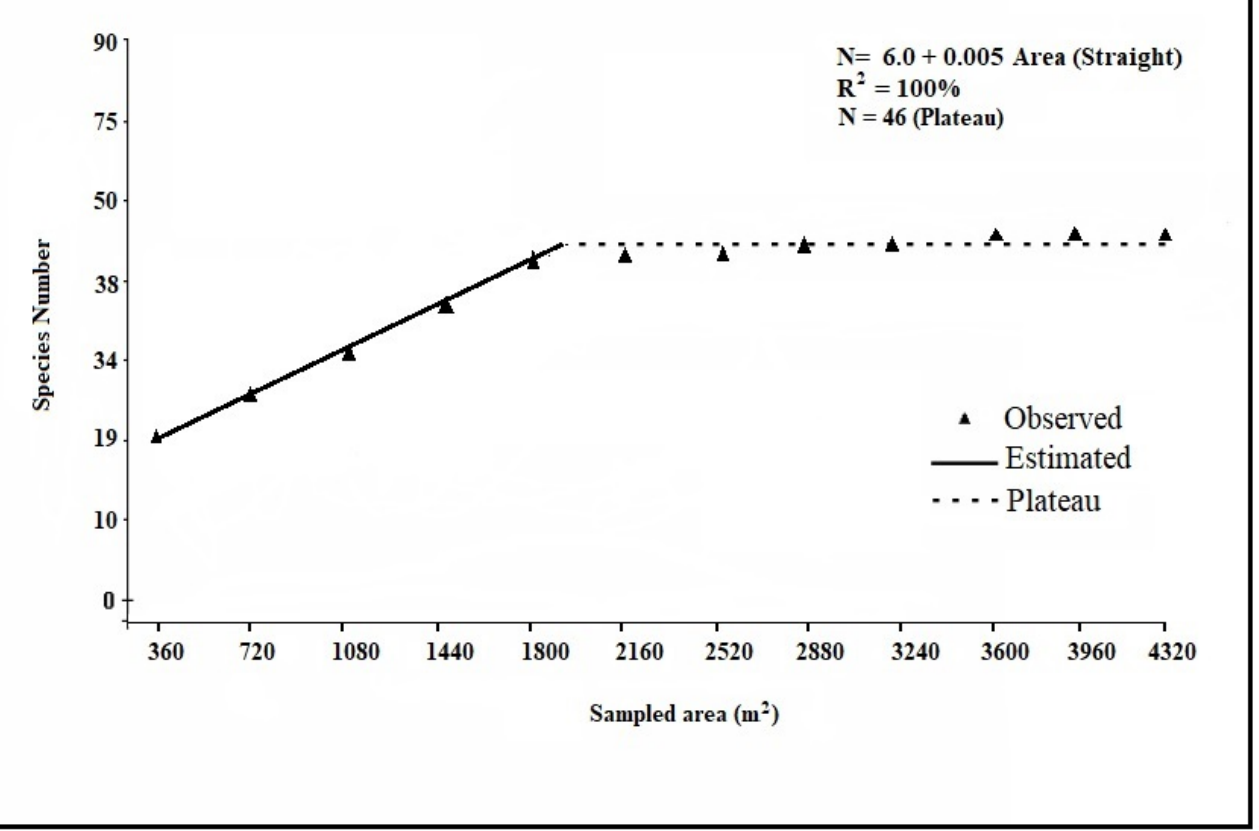

Figure 2. Graphic representation of sample sufficiency of the Cerrado fragment, Serra do Boqueirão, Lavras da Mangabeira, Ceará.

The inventory, with a total of 906 arboreal individuals, generated an estimative of absolute density of 2,097.22 ind.ha ${ }^{-1}\left(\mathrm{IC}= \pm 202.67\right.$ ind.ha $\left.^{-1}\right)$ at $95 \%$ probability and $6.16 \%$ standard error; a basal area (dominance) estimate of $5.17 \mathrm{~m}^{2} \mathrm{ha}^{-1}\left(\mathrm{IC}= \pm 6.93 \mathrm{~m}^{2} \mathrm{ha}^{-1}\right.$ ) at $95 \%$ of probability and $8.09 \%$ standard error. These values agree with an adequate and comprehensive sampling precision for the estimation of quantitative variables (Felfili \& Rezende, 2003).

\section{Floristic composition and diversity}

The sampled individuals belong to 46 species distributed among 43 genera and 22 botanical families (Table 1). The species-richest families were: Fabaceae (11), Bignoniaceae (4), Malvaceae (4), Rubiaceae (3) and Salicaceae (3), which corresponds to $54.3 \%$ of the total of species sampled. Four other families had two species and thirteen families had individuals from only one species. Fabaceae included $23.9 \%$ of the species found. 
Table 1: Floristic composition of a Cerrado fragment, Serra do Boqueirão, Lavras da Mangabeira, Northeast of Brazil.

\begin{tabular}{|c|c|c|c|c|}
\hline Family & Species & Common Name & Dominion & Voucher \\
\hline \multirow{2}{*}{ Anacardiaceae } & Anacardium occidentale var. microcarpum & Cajuí & Cer & 13690 \\
\hline & Astronium fraxinifolium Schott & Gonçalo-Alves & Cer & 13691 \\
\hline Annonaceae & Annona leptopetala (R.E.Fr.) H.Rainer & Bananinha & Cer & 13492 \\
\hline \multirow{2}{*}{ Apocynaceae } & Aspidosperma cuspa (Kunth) S.F. Blake & Pereiro-branco & Cer & 13822 \\
\hline & Aspidosperma pyrifolium var. molle (Mart.) Müll.Arg. & Pereiro-preto & Caa & 13531 \\
\hline \multirow{3}{*}{ Bignoniaceae } & Cuspidaria argentea (Wawra) Sandwith & Cipó-rosa & Cer & 13466 \\
\hline & Handroanthus impetiginosus (Mart. ex DC.) Mattos & Ipê-roxo & Cer & 13541 \\
\hline & $\begin{array}{l}\text { Tabebuia aurea (Silva Manso) Benth \& Hook.f. ex S. } \\
\text { Moore }\end{array}$ & Craibeira & Cer & 13612 \\
\hline & Jacaranda caroba (Vell.) DC. & Caroba-boca-de-sapo & Cer & 13464 \\
\hline Bixaceae & Cochlospermum vitifolium (Willd.) Spreng. & Pacoté & Caa & 13652 \\
\hline Burseraceae & $\begin{array}{l}\text { Commiphora leptophloeos } \\
\text { (Mart.)J.B.Gillett }\end{array}$ & Umburana-de-cambão & Caa & 13495 \\
\hline Cactaceae & Cereus jamacaru DC. & Mandacaru & Caa & - \\
\hline \multirow{2}{*}{ Combretaceae } & Combretum glaucocarpum Mart. & Sipaúba & Caa & 13535 \\
\hline & Combretum leprosum Mart. & Mofumbo & Caa & 14048 \\
\hline Dilleniaceae & Curatella americana $\mathrm{L}$. & Lixeira & Cer & 13688 \\
\hline \multirow[t]{6}{*}{ Euphorbiaceae } & Croton jacobinensis Baill. & Marmeleiro & Caa & 13497 \\
\hline & Dahlstedria araripensis (Benth.) & Angelim & Cer & 13693 \\
\hline & Amburana cearensis (Allemão) A.C.Sm. & Umburana-de-cheiro & Caa & - \\
\hline & Dalbergia cearenses Ducke & Violete & Caa & - \\
\hline & Plathymenia reticulata Benth. & Pau-amarelo & Cer & 13692 \\
\hline & Luetzelburgia auriculata (Allemão) Ducke & Pau-mocó & Caa & 13651 \\
\hline \multirow[t]{6}{*}{ Fabaceae } & Hymenaea stigonocarpa Mart. ex Hayne & Jatobá-de-veado & Cer & 13647 \\
\hline & Bauhinia sp. & Pata-de-vaca & Caa & - \\
\hline & Libidibia ferrea (Mart. ex Tul.) L.P.Queiroz & Pau-ferro & Caa & 13611 \\
\hline & Machaerium acutifolium Vogel & Coração-de-negro & Cer & - \\
\hline & Mimosa tenuiflora (Willd.) Poir. & Jurema-preta & Caa & - \\
\hline & Vatairea macrocarpa (Benth.) Ducke & Amargoso & Cer & - \\
\hline Lythraceae & $\begin{array}{l}\text { Lafoensia vandelliana Cham. \& Schldt. Subsp. } \\
\text { vandelliana }\end{array}$ & Romã-brava & Cer & 13584 \\
\hline \multirow[t]{3}{*}{ Malpighiaceae } & Byrsonima gardneriana A. Juss. & Murici & Cer & 13493 \\
\hline & Helicteres macropetala A. St.-Hil. & Saca-rolha & Cer & 13557 \\
\hline & Luehea candicans Mart. \& Zucc. & Açoita-cavalo1 & Cer & 13556 \\
\hline \multirow[t]{2}{*}{ Malvaceae } & Luehea paniculata Mart. \& Zucc. & Açoita-cavalo2 & Cer & $54641 *$ \\
\hline & $\begin{array}{l}\text { Pseudobombax marginatum (A.St.-Hil., Juss. \& } \\
\text { Cambess.) A.Robyns }\end{array}$ & Embiratanha & Caa & - \\
\hline Moraceae & Brosimun gaudichaudii Trécul & Inharé & Cer & 13689 \\
\hline Myrtaceae & Psidium myrsinites DC. & Araçá-bravo & Cer & 13537 \\
\hline \multirow[t]{2}{*}{ Olacaceae } & Ximenia americana L. & Ameixa & Caa & - \\
\hline & Coutarea hexandra (Jacq.) K.Schum. & Quína-Quina & Cer & $54746 *$ \\
\hline \multirow[t]{2}{*}{ Rubiaceae } & $\begin{array}{l}\text { Guettarda viburnoides } \\
\text { Cham. \& Schltdl. }\end{array}$ & Veludo-branco & Cer & 13491 \\
\hline & Tocoyena formosa (Cham. \& Schltdl.) K.Schum. & Jenipapo & Cer & 13483 \\
\hline \multirow[t]{2}{*}{ Rutaceae } & Zanthoxylum sp. & Laranjinha & Cer & - \\
\hline & Laetiasp. & Pau-piranha & Caa & 13467 \\
\hline \multirow[t]{2}{*}{ Salicaceae } & Prockia crucis P. Browne ex L. & Farinha-seca & Cer & $54741 *$ \\
\hline & Xylosma ciliatifolia (Clos) Eichler & Espinho-de-judeu & Cer & - \\
\hline Simaroubaceae & Simarouba amara Aubl. & Pau-Paraíba & Cer & 13648 \\
\hline \multirow{2}{*}{ Vochysiaceae } & Qualea parviflora Mart. & Pau-terra & Cer & 13463 \\
\hline & Callisthene fasciculata Mart. & Carvoeiro & Cer & 13462 \\
\hline
\end{tabular}

*Identified species at Herbário Prisco Bezerra (EAC), Universidade Federal do Ceará - UFC. Cer = Cerrado; Caa = Caatinga.

Like many other tropical forests, a richness of the family Fabaceae was observed (Matos; Felfili, 2010). According to Cordeiro (2002) in the Cerrado this family is associated to the capacity of symbiotic nitrogen fixation, which represents an adaptive advantage under unbalanced environmental conditions. 
According to Pereira et al. (2011), the richest families in Cerrado stricto sensu are: Fabaceae, Malvaceae, Anacardiaceae, Apocynaceae and Bignoniaceae, and the richness of each family varies between localities and usually the sum of species numbers is above $50 \%$ of the total per hectare, which corroborates with the results of this study. Mendonça et al. (2008) state that the presence of the families Vochysiaceae, Fabaceae and Myrtaceae is frequent in Central Brazilian Cerrado.

Studies made at Chapada do Araripe, Ceará (ca. $50 \mathrm{Km}$ in a straight line from the sampling site) in an area of Cerrado s.s. (Barbalha municipality) by Costa \& Araújo (2007) and Bezerra (2018) in a "cerradão" area at Crato municipality had shown similar results about family representativity and taxon numbers. Other studies made in Cerrado areas in different regions of Brazil corroborate these studies: Medeiros et al. (2008), Lemos et al. (2013) and Oliveira et al., (2015) in the Northeastern Cerrado; Saporetti-Junior et al. (2003); Assunção \& Felfili (2004), Matos \& Felfili (2010) and OestreichFilho (2014) in the central region Cerrado.

As for the number of individuals, the seven best represented families corresponded to $80.3 \%$ of the total of individuals sampled, which are distributed as follows: Fabaceae (20.3\%), Vochysiaceae (19.9\%) Anacardiaceae (11.1\%), Annonaceae (9.6\%), Bignoniaceae (6.7\%), Rubiaceae (6.6\%) and Myrtaceae (6.1\%). The remaining families had values below $5 \%$ individuals. Similar results were obtained by Gentry et al. (1997) and Mendonça et al. (1998), who have shown Fabaceae and Vochysiaceae as the best represented families of the Central Brazilian Cerrado, in terms of number of individuals. These results agree with the tendency of a few families dominating others in the phytophysiognomies of Cerrado s.s. in Brazil (Sampaio et al., 2018).

The success of the family Vochysiaceae is probably associated to the capacity of aluminum accumulation by some of its species (Haridasan, 2000; Mews et al., 2011), which represents a competitive advantage in dystrophic soils with low saturation of interchangeable bases, low cationic exchange capacity, high acidity and high aluminum concentration, as is the case of most soils of the Cerrado biome. Furthermore, many species of those families have reproductive strategies welladapted to the climatic conditions of the Cerrado, with seed dispersal in the beginning of the wet season, good germination ratio and absence of seed dormancy (Oliveira, 2008).

The alpha diversity index of Shannon-Weaver ( $H$ ) was 3.18; the equitability of Pielou (/) was 0.83 and the concentration index of Simpson $(C)$ was 0.05 . These values suggest a high species richness (and thus an elevated alpha diversity), a high uniformity of the size of the populations and a low concentration of species. According to Saporetti Junior et al. (2003), $H^{\prime}$ values beyond 3.11 indicate well-preserved plant formations. Hypothetically, the value of $J^{\prime}$ obtained suggests that a total of only $17 \%$ of species reaches the maximum diversity in the community, according to Brower et al. (1998).

Results agreeing with this study were appointed by Silva-Neto et al. (2016), in which values of $H^{\prime}$ e J'were respectively 3.21 and 0.86 in a Cerrado s.s. area in Tocantins state, Central Brazil. In this case, it was possible to observe a tentatively high floristic heterogeneity of the arboreal component, along with a low ecological dominance.

The alpha diversity in the Cerrado spot at the Serra do Boqueirão is considered high in comparison with the typical semiarid Caatinga areas, in which the Shannon-Weaver indexes vary from 1.10 to 3.09 (Calixto Júnior \& Drumond, 2014). Medeiros et al. (2008) point to Shannon-Weaver values between 3.11 and 3.62 as representative for many areas of the central Cerrado in Mato Grosso, Minas Gerais and Goiás states and Distrito Federal.

The presence of rare species is not usual, having only two (Prockia crucis e Luetzelbugia auriculata) occurring isolated (only one individual registered) and four others (Coutarea hexandra, Pseudobombax marginatum, Helicteres macropetala e Mimosa tenuiflora) registered only two individuals. Thirteen species $(28,2 \%)$ are represented by five or less individuals.

P. crucis and H. macropetala are cited in phytosociological surveys in Southern Ceará for the first time in this study.

Thirty species in the sample (65.5\%) are typical of Cerrado environments. The remainder of species (34.8\%) are characteristic of the Caatinga that penetrate the enclave and with this intromission, compete with the Cerrado species, without, however, shading the physiognomy, as observed by Figueiredo \& Fernandes (1987). Pseudobombax marginatum and Mimosa tenuiflora, correspond to $8.6 \%$ of the sampled individuals, along with 14 other typical Caatinga species. 
Aspidosperma pyrifolium (12 espécimes), Ximenia americana (8) and Amburana cearensis (6) are typical examples.

Also important to note is the presence of eleven individuals of Curatella americana ("lixeira" or "simbaíba") an abundant species of the Central Cerrado, but absent in surveys at the s.s. Cerrado of Chapada do Araripe (Costa \& Araújo, 2007) or occurring in low frequencies in savanna vegetation on pre-coastal "tabuleiros" in Fortaleza, Ceará (Moro et al., 2011).

Curatella americana is considered a colonizer and even a pioneer in savanna areas, given its performance and adaptive potential (Winterhalder, 1996; Calgaro et al., 2015) and due to its adaptations to fire resistance, like cracked stem and wide leaves. It is a typical example of a larger physiognomy that covered that area in the past, today represented only as a vegetation relict. According to Figueiredo \& Fernandes (1987), this fact is evidenced by the global evolution of the landscape, especially the surface and soil structure. The deep weathering occurring in the semiarid confirms the occurrence of climatic conditions that were different from those occurring today, which allowed the development of the phytogeographic profile of Serra do Boqueirão and other Cerrado spot areas.

The occurrence of $C$. hexandra ("quina-quina"), a rare species of high therapeutic value, creates a demand for studies like this one, since species with similar characteristics have been decimated through human history, as well as the fragment in study, which has been suffering severe damage for either climate change and anthropic actions like the development industry and the weakening of environment conservation actions through public policies, both observed at sites in Serra do Boqueirão, what affects the resistance and resilience of this relict plant community.

Castro et al. (1998) warn about the risks of the lack of knowledge of the floristic patrimony of the Cerrado, considering it as a problem that could negatively affect the supply of genetic variability for future generations, and in addition points out that the phyto-diversity and the compartmentalized architecture of the Cerrado biome hinders the extrapolation of results achieved by quantitative floristic surveys.

\section{Analysis of phytosociological parameters}

The values of total basal area and total absolute density were respectively $5.17 \mathrm{~m}^{2} / \mathrm{ha}^{-1}$ and 2,097.22 ind./ha-1. Similar values were found by Felfili et al. (1997), who compared eleven areas on the Chapada of Pratinha and Chapada dos Veadeiros (Central Brazilian Cerrado) and calculated basal area values from 5.8 to $11.3 \mathrm{~m}^{2} / \mathrm{ha}^{-1}$. Incidentally, the basal area value found in this study differs from the one of Costa \& Araujo (2007) at the Chapada do Araripe (Barbalha, Ceará), which was of $19.2 \mathrm{~m}^{2} / \mathrm{ha}^{-1}$, despite the convergence in the absolute density value $\left(2.224 \mathrm{~m}^{2} / \mathrm{ha}^{-1}\right)$. This is explained by the pedological and altitudinal differences between the two sites, since the Chapada shows an arboreal community that configures a "Cerradão" physiognomy, characteristic of more elevated areas (ca. $950 \mathrm{~m}$ ) and deep and sandy soils. Species like the "Pequi" (Caryocar coriaceum Wittm.) and the "Visgueiro" (Parkia platycephala Benth), for example, have high values of basal area when adult, dominating the environments where they concentrate, being present in high numbers in the "Cerradão" of the Chapada do Araripe, but do not survive the different conditions of the tabletops of lesser elevation of Serra do Boqueirão, with a higher average temperature and a smaller precipitation regime.

Medeiros et al. (2008) presented a total basal area value of $6.8 \mathrm{~m}^{2} / \mathrm{ha}^{-1}$ in a study made in a "thin Cerrado" in Maranhão state, Northeastern Brazil, with a remarkable similarity with Serra do Boqueirão at Lavras da Mangabeira.

The density and basal area in different Cerrado communities is highly variable, densities from 664 through 8.135 individuals per hectare and basal areas from $4.73 \mathrm{~m}^{2} / \mathrm{ha}$ to $42.19 \mathrm{~m}^{2} / \mathrm{ha}$ (Costa \& Araújo, 2007; Moro et al., 2011). This is due to the large physiognomic variation of the Cerrado sensu lato, covering from forest ("Cerradão") to grassland ("campo limpo") landscapes (Gottsberger \& Silberbauer-Gottsberger, 2006; Ribeiro \& Walter, 2008). Intermediate (savanna) physiognomies are those classified as Cerrado sensu stricto (Ribeiro \& Walter, 2008), and the density and basal area of the studied fall within those registered for other Cerrado sensu stricto areas (Felfili et al., 2002; Fidelis \& Godoy, 2003; Moro et al., 2011). 
The species with highest importance value (IVI) were: A. occidentale, Q. parviflora, H. stignocarpa, C. fasciculata and A. leptopetala (Table 2). Sampaio et al. (2018) obtained similar results in a Cerrado sensu stricto area at the Rio Parnaíba basin, Northeastern Brazil, in which Q. parviflora was the highest IVI species.

Table 2: Phytosociological parameters of the Cerrado fragment on Serra do Boqueirão, Lavras da Mangabeira, Northeastern Brazil. Decreasing values by Importance Value Index (IVI), where: $N=$ Number of Individuals; $A D=$ Absolute Density; $\mathrm{AF}=$ Absolute Frequency; $\mathrm{ADo}=$ Absolute Dominance; $\mathrm{RD}=$ Relative Density (\%); RF = Relative Frequency (\%); RDo = Relative Dominance (\%); CVI = Cover Value Index and IVI = Importance Value Index.

\begin{tabular}{|c|c|c|c|c|c|c|c|c|c|}
\hline Species & $\mathbf{N}$ & AD & RD & AF & $\mathbf{R F}$ & ADo & RDo & CVI & IVI \\
\hline A. occidentale & 71 & 164.4 & 7.84 & 91.67 & 5.31 & 3.01 & 25.14 & 32.98 & 38.29 \\
\hline Q. parviflora & 103 & 238.4 & 11.7 & 66.67 & 3.86 & 1.04 & 8.66 & 20.02 & 23.89 \\
\hline H. stignocarpa & 85 & 196.8 & 9.38 & 33.33 & 1.93 & 1.29 & 10.75 & 20.13 & 22.07 \\
\hline C. fasciculata & 78 & 180.6 & 8.61 & 91.67 & 5.31 & 0.66 & 5.5 & 14.1 & 19.42 \\
\hline A. leptopetala & 87 & 201.4 & 9.6 & 83.33 & 4.83 & 0.42 & 3.48 & 13.08 & 17.91 \\
\hline G. virbunoides & 54 & 125 & 5.96 & 58.33 & 3.38 & 0.6 & 4.98 & 10.94 & 14.32 \\
\hline P. myrsinites & 56 & 129.6 & 6.18 & 75.00 & 4.35 & 0.24 & 2.04 & 8.22 & 12.57 \\
\hline A. fraxinifolium & 30 & 69.4 & 3.31 & 91.67 & 5.31 & 0.42 & 3.5 & 6.81 & 12.13 \\
\hline D. cearensis & 19 & 44 & 2.1 & 91.67 & 5.31 & 0.45 & 3.73 & 5.83 & 11.15 \\
\hline D. araripensis & 15 & 34.7 & 1.66 & 58.33 & 3.38 & 0.66 & 5.51 & 7.17 & 10.55 \\
\hline H. impetiginosus & 27 & 62.5 & 2.98 & 83.33 & 4.83 & 0.28 & 2.35 & 5.33 & 10.16 \\
\hline P. reticulata & 26 & 60.2 & 2.87 & 50.00 & 2.9 & 0.39 & 3.29 & 6.16 & 9.06 \\
\hline A. cuspa & 29 & 67.1 & 3.2 & 66.67 & 3.86 & 0.1 & 0.8 & 4 & 7.86 \\
\hline C. argentea & 19 & 44 & 2.1 & 83.33 & 4.83 & 0.08 & 0.7 & 2.79 & 7.63 \\
\hline B. gaudichaudii & 20 & 46.3 & 2.21 & 33.33 & 1.93 & 0.39 & 3.29 & 5.49 & 7.43 \\
\hline C. americana & 11 & 25.5 & 1.21 & 25.00 & 1.45 & 0.38 & 3.13 & 4.34 & 5.79 \\
\hline T. aurea & 15 & 34.7 & 1.66 & 25.00 & 1.45 & 0.21 & 1.77 & 3.42 & 4.87 \\
\hline A. pyrifolium & 12 & 27.8 & 1.32 & 50.00 & 2.9 & 0.06 & 0.53 & 1.86 & 4.76 \\
\hline B. crassifolia & 12 & 27.8 & 1.32 & 41.67 & 2.42 & 0.06 & 0.53 & 1.86 & 4.27 \\
\hline L. replicata & 20 & 46.3 & 2.21 & 16.67 & 0.97 & 0.08 & 0.65 & 2.86 & 3.82 \\
\hline X. americana & 7 & 16.2 & 0.77 & 41.67 & 2.42 & 0.02 & 0.17 & 0.94 & 3.36 \\
\hline C. vitifolium & 5 & 11.6 & 0.55 & 33.33 & 1.93 & 0.09 & 0.76 & 1.31 & 3.24 \\
\hline M. acutifolium & 7 & 16.2 & 0.77 & 16.67 & 0.97 & 0.17 & 1.45 & 2.22 & 3.19 \\
\hline Zanthoxylum sp. & 6 & 13.9 & 0.66 & 33.33 & 1.93 & 0.07 & 0.59 & 1.25 & 3.18 \\
\hline C. glaucocarpum & 5 & 11.6 & 0.55 & 25.00 & 1.45 & 0.12 & 1.04 & 1.59 & 3.04 \\
\hline A. cearensis & 6 & 13.9 & 0.66 & 33.33 & 1.93 & 0.05 & 0.4 & 1.06 & 2.99 \\
\hline C. jamacaru & 5 & 11.6 & 0.55 & 25.00 & 1.45 & 0.1 & 0.84 & 1.39 & 2.84 \\
\hline J. caroba & 6 & 13.9 & 0.66 & 25.00 & 1.45 & 0.06 & 0.5 & 1.16 & 2.61 \\
\hline V. macrocarpa & 8 & 18.5 & 0.88 & 16.67 & 0.97 & 0.07 & 0.6 & 1.48 & 2.45 \\
\hline L. paniculata & 4 & 9.3 & 0.44 & 25.00 & 1.45 & 0.06 & 0.51 & 0.95 & 2.4 \\
\hline Laetia sp. & 4 & 9.3 & 0.44 & 25.00 & 1.45 & 0.06 & 0.46 & 0.9 & 2.35 \\
\hline L. candicans & 8 & 18.5 & 0.88 & 16.67 & 0.97 & 0.04 & 0.35 & 1.23 & 2.2 \\
\hline C. leptopholeos & 3 & 6.9 & 0.33 & 25.00 & 1.45 & 0.04 & 0.29 & 0.63 & 2.08 \\
\hline Xylosma sp. & 5 & 11.6 & 0.55 & 16.67 & 0.97 & 0.04 & 0.32 & 0.87 & 1.84 \\
\hline C. jacobinensis & 5 & 11.6 & 0.55 & 16.67 & 0.97 & 0.02 & 0.18 & 0.73 & 1.7 \\
\hline L. ferrea & 4 & 9.3 & 0.44 & 16.67 & 0.97 & 0.03 & 0.28 & 0.72 & 1.68 \\
\hline Bauhinia sp. & 5 & 11.6 & 0.55 & 16.67 & 0.97 & 0.02 & 0.15 & 0.7 & 1.66 \\
\hline C. leprosum & 4 & 9.3 & 0.44 & 16.67 & 0.97 & 0.02 & 0.16 & 0.6 & 1.57 \\
\hline T. formosa & 4 & 9.3 & 0.44 & 16.67 & 0.97 & 0.01 & 0.11 & 0.55 & 1.52 \\
\hline S. amara & 6 & 13.9 & 0.66 & 8.33 & 0.48 & 0.02 & 0.19 & 0.85 & 1.33 \\
\hline C. hexandra & 2 & 4.6 & 0.22 & 16.67 & 0.97 & 0 & 0.04 & 0.26 & 1.22 \\
\hline P. marginatum & 2 & 4.6 & 0.22 & 8.33 & 0.48 & 0.01 & 0.1 & 0.32 & 0.8 \\
\hline H. macropetala & 2 & 4.6 & 0.22 & 8.33 & 0.48 & 0.01 & 0.06 & 0.28 & 0.77 \\
\hline M. tenuiflora & 2 & 4.6 & 0.22 & 8.33 & 0.48 & 0 & 0.04 & 0.26 & 0.75 \\
\hline L. auriculata & 1 & 2.3 & 0.11 & 8.33 & 0.48 & 0.01 & 0.05 & 0.16 & 0.65 \\
\hline P. crucis & 1 & 2.3 & 0.11 & 8.33 & 0.48 & 0 & 0.04 & 0.15 & 0.63 \\
\hline
\end{tabular}


Twenty-two species presented IVI values below 3.8\%, what represents less than 10\% of the maximum observed value (38.29\%), what indicates that these species are uncommon at the studied area, $50 \%$ of them being characteristic from the Caatinga, entering the fragment as competitors.

In this study, Q. parviflora was the most abundant species, followed by A. leptopetala, $H$. stignocarpa and C. fasciculata. Among those are two species of the family Vochysiaceae, a dominant family of Cerrado but unrecorded in the surveys made in the Caatinga, among the foremost representative (in number of individuals) of the sampled flora. The "Cajui" (Anacardium occidentale) is another species that occurs in large numbers, being shown also as one of the greatest IVI index only by Moro et al. (2011) in other surveys at Northeastern Cerrado. This can be due to the scarcity of phytosociological descriptions in marginal areas of Cerrado in Ceará or to the mix of environmental factors such as soil composition, rainfall and elevation particular to the Serra do Boqueirão. On the other side, this species is considered as common in savanna formations (Ratter et al., 2003), especially at the North-Northeast part of the Cerrado biome, where it is widely abundant (Castro et al., 1998; Oliveira-Filho, 2006; Matos \& Felfili, 2010).

\section{Diametric and hypsometric distribution}

The graph representing the studied community, by the distribution of individuals per diameter classes, is shaped as "reverse-J" (negative exponential), being composed mostly of young trees, with $68.1 \%$ of diameter equal or less than $8 \mathrm{~cm}$ (Figure 3). The average diameter value was of $7.26 \mathrm{~cm}$. The maximum diameter encountered was of $36.3 \mathrm{~cm}$ in an individual of A. occidentale (the most abundant species of the area).

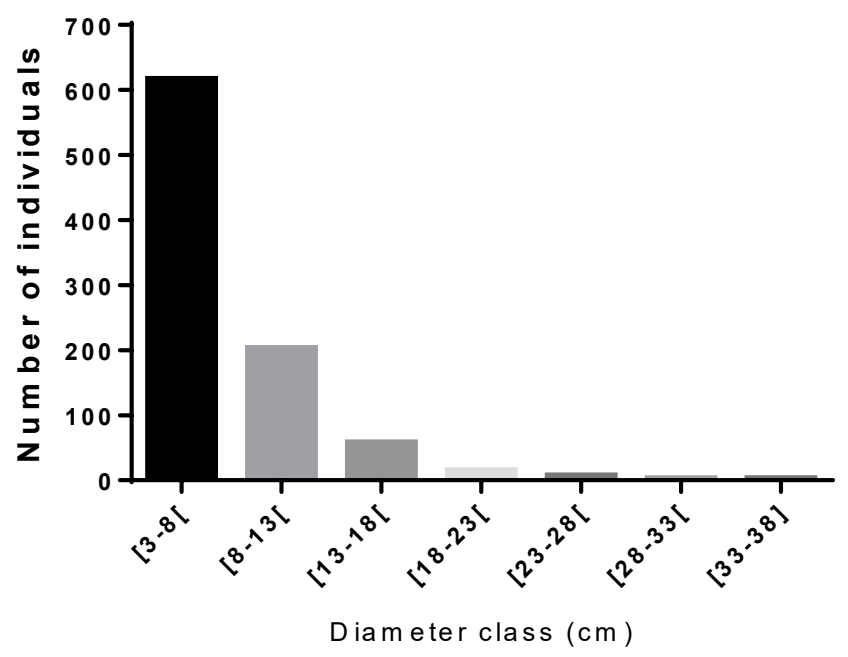

Figure 3: Distribution of individuals per diameter class in a Cerrado fragment at Lavras da Mangabeira, Northeastern Brazil.

These data corroborate the results obtained by Assunção \& Felfili (2004) in a Cerrado sensu stricto area at Distrito Federal, in which a "reverse-J" diametric distribution was also found; the survey made by Ferreira et al. (2015) in a Cerrado sensu stricto area at Tocantins state showed similar results too, with $75 \%$ of the young individuals with diameters of less than $12 \mathrm{~cm}$. The class distribution with a "reverse-J" pattern suggests that the area is selfregenerative (Assunção \& Felfili, 2004; Ferreira et al., 2015; Cerqueira et al., 2017). The large amount of young individuals, with a diameter of less than $8 \mathrm{~cm}$, points to an area in recovery after perturbations, which reinforces the need for preservation efforts. The possibility of selfregeneration contrasts with the increase of anthropic actions at the area, which along with climatic and edaphic factors hinders the development of that fragment. 
According to Marangon et al. (2008), the observation of the development stage of forest formations is possible through analysis of the vertical structure, based on the distribution of individuals in the different levels of height classes, along with the data obtained in the diametric classes.

In the distribution of height classes (Figure 4), the highest concentration of individuals was at the intermediary classes, what corresponds to $68.3 \%$ of the total. Class 2 (5-7.9 cm height) by itself represents $45.3 \%$ of all individuals of the survey. However, 120 individuals (13\%) have a height larger than $11 \mathrm{~m}$, what is similar to the arboreal stratus of "Cerradão".

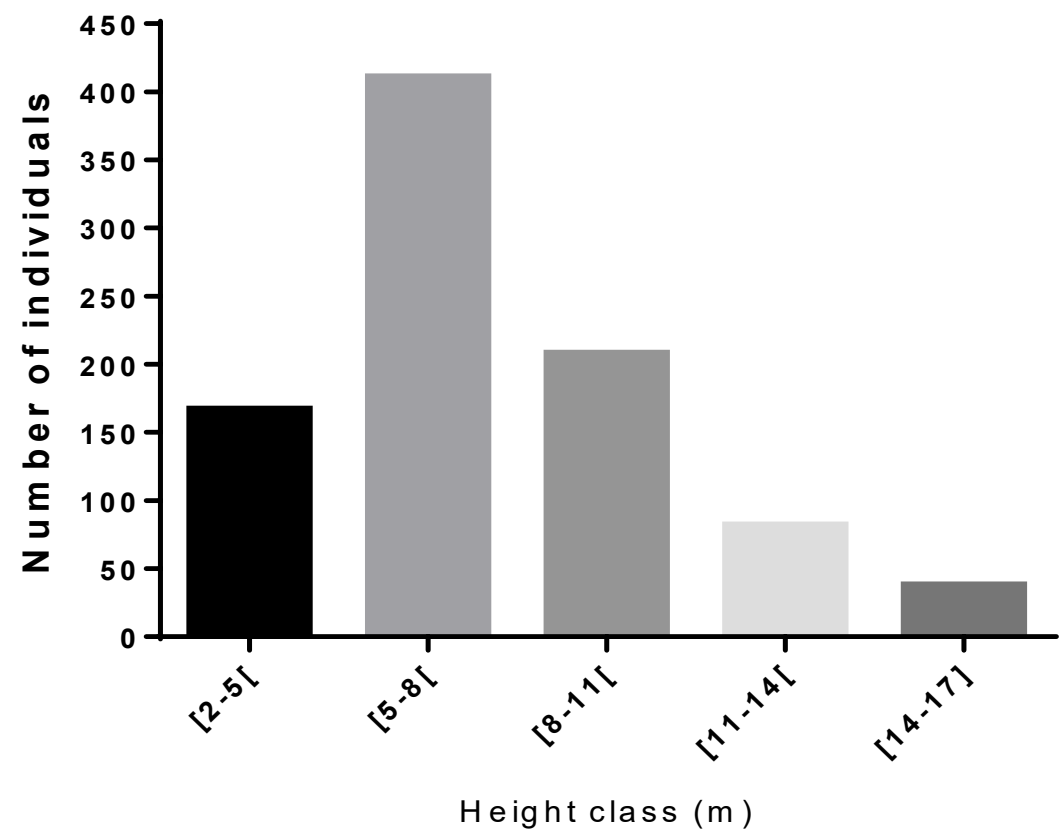

Figure 4: Distribution of individuals per height class in a Cerrado fragment at Lavras da Mangabeira, Northeastern Brazil.

The data from diameter and height classes were similar to the results obtained by Ferreira et al. (2015) in a survey made at a Cerrado sensu stricto in Gurupi, Tocantins, where the average height was of $7.31 \mathrm{~m}$. This data corroborate those found by Assunção \& Felfili (2004) in a study made at APA Lago Paranoá, Brasília and suggest that the Cerrado fragment of Serra do Boqueirão is in a phyto-physiognomic transition process.

The largest height registered was that of $17 \mathrm{~m}$ in some individuals of $D$. araripensis ("Angelim"). The total hypsometric average was of $7.15 \mathrm{~m}$; a value which approaches the inclusion criterion that classifies the forest formations of the Cerrado biome, which is of $8 \mathrm{~m}$ (Ferreira et al., 2015).

\section{Similarity analysis}

According to Magurran (1988), the beta diversity, or diversity among habitats is related with the differences between composition of species and their abundance between communities, which reflects floristic dissimilarity (Matos \& Felfili, 2010).

The floristic similarity indexes (Jaccard matrix) calculated from the studied area and ten other Cerrado areas in different regions of Brazil are shown on Table 3 and point to the high heterogeneity between the areas, with low values of floristic similarity, which represents a high beta diversity among the studied area and the remaining ones. 
Table 3. Similarity of Jaccard matrix for eleven Cerrado areas in different regions of Brazil.

\begin{tabular}{|c|c|c|c|c|c|c|c|c|c|c|c|}
\hline & A & B & C & D & $\mathbf{E}$ & $\mathbf{F}$ & G & $\mathbf{H}$ & I & J & K \\
\hline A & 1 & & & & & & & & & & \\
\hline B & 0.0737 & 1 & & & & & & & & & \\
\hline C & 0.08 & 0.1764 & 1 & & & & & & & & \\
\hline D & 0.0652 & 0.2752 & 0.2428 & 1 & & & & & & & \\
\hline E & 0.1153 & 0.2517 & 0.2407 & 0.2177 & 1 & & & & & & \\
\hline $\mathbf{F}$ & 0.1525 & 0.1263 & 0.0961 & 0.0882 & 0.0901 & 1 & & & & & \\
\hline G & 0.1408 & 0.1650 & 0.2280 & 0.1917 & 0.2407 & 0.1632 & 1 & & & & \\
\hline H & 0.0987 & 0.2549 & 0.3220 & 0.4179 & 0.2792 & 0.1206 & 0.2187 & 1 & & & \\
\hline I & 0.0416 & 0.2127 & 0.2075 & 0.1095 & 0.1743 & 0.1333 & 0.1428 & 0.0909 & 1 & & \\
\hline$J$ & 0.1296 & 0.0989 & 0.0869 & 0.1551 & 0.0961 & 0.0882 & 0.1363 & 0.1153 & 0.0101 & 1 & \\
\hline k & 0.0816 & 0.4646 & 0.1728 & 0.3827 & 0.2230 & 0.0789 & 0.1728 & 0.3205 & 0.1558 & 0.1363 & 1 \\
\hline
\end{tabular}

According to Kent \& Coker (1992), values of comparison indexes equal or higher than 0.5 point to a high similarity. So, the similarity observed with the Jaccard index between the areas is considered low. The comparison indexes between the Serra do Boqueirão Cerrado and ten other areas varied from 0.0416 (Cerrado s.s. in Pirinópolis, Goiás state) to 0.1525 (urbanized area of Fortaleza, Ceará state), revealing a higher similarity with a savanna vegetation spot on a pre-coastal table in Ceará state, with an average annual rainfall of 1,338 $\mathrm{mm}$ (Table 4). In comparison with another area in Ceará state, Cerrado s.s. of Chapada do Araripe, Barbalha (ca. $50 \mathrm{Km}$ in a straight line from the study site), the third largest similarity of the analysis observed (0.1296) had a lower value in comparison with the Cerrado s.s. in Carolina, southern Maranhão state.

The low floristic similarity evidenced in this study between areas geographically next to each other, as well as more distant areas, confirms the hypothesis of the existence of phytogeographical patterns based on the distribution of the species. The differences observed suggest that the species of tropical forests are characterized by having a mosaic spatial distribution and even the communities located in nearby areas are floristic and structurally different, which agrees with study results that report a high diversity of the flora of tropical areas like the Brazilian Cerrado (Ferreira-Júnior et al., 2008).

Table 4: Floristic/environmental variables between 11 areas (A-K) of Cerrado located at Northeast, Central-west and Southeast Regions of Brazil.

\begin{tabular}{|c|c|c|c|c|c|c|c|}
\hline Area & SN & FN & SA/ha & ARF/mm & Elv/m & $\mathrm{IC} / \mathrm{cm}$ & $A D m^{2} / h a^{-1}$ \\
\hline$A$ & 46 & 22 & 0.43 & 904 & 289 & $\mathrm{DNS} \geq 3$ & 2097 \\
\hline B & 85 & 44 & 0.30 & 1400 & 480 & $C A S \geq 10$ & 4463 \\
\hline C & 41 & 21 & 0.20 & 1500 a 1600 & 329 & $C A P \geq 15$ & -- \\
\hline D & 54 & 30 & 1.00 & 1400 a 1450 & 1050 & $\mathrm{DNS} \geq 5$ & 882 \\
\hline$E$ & 114 & 36 & 3.28 & -- & 500 & $\mathrm{DNS} \geq 5$ & 1740 \\
\hline $\mathrm{F}$ & 37 & 24 & 1.00 & 1338 & 16 & $\mathrm{PNS} \geq 9$ & 1218 \\
\hline G & 53 & 25 & 1.00 & 1718 & 150 & $D N S \geq 5$ & -- \\
\hline $\mathrm{H}$ & 58 & 24 & 2.00 & 1059 & 918 & $\mathrm{DNS} \geq 5$ & 1027 \\
\hline I & 83 & 38 & 0.40 & 1500 & 810 & $D A P \geq 5$ & 1855 \\
\hline$J$ & 43 & 28 & 0.08 & 760 & 900 & $D N S \geq 3$ & 2224 \\
\hline K & 91 & 38 & 0.60 & 1059 & 918 & $C A S \geq 10$ & 6476 \\
\hline
\end{tabular}

Where: A = Serra do Boqueirão, Southern Ceará (this study); B = Saporetti-Junior et al. (2003), Abaeté, Minas Gerais; C = Silva-Neto et al. (2016), Dueré, Tocantins; D = Assunção \& Felfili (2004), APA do Paranoá, Distrito Federal; E = Finger \& Finger (2015), Chapada dos Guimarães and Baixada Cuiabana, Mato Grosso; F = Moro et al. (2011) urbanized zone of Fortaleza, Ceará; G = Medeiros et al. (2008), Carolina, Maranhão; H = Oliveira et al. (2015), Jaborandi, Western Bahia; I = ImañaEncinas et al. (2007) EcoMuseu do Cerrado, Pirinópolis, Goiás; J = Costa \& Araújo (2007), Chapada do Araripe, Barbalha, Ceará; K = Neri et al. (2007) Rio Jequitinhonha basin, Minas Gerais. Onde: SN = Species number; FN = Family number; SA = Sample area; ARF = Annual Rainfall; Elv. = Elevation; IC = Inclusion Criterion and DA = Total absolute density. 
The analysis of the connection distance diagram shown in Figure 5 points to the formation of two groups, dependent on the location of the areas, stating that there is a link between geographical location and group formation. The first group was formed only in Ceará state areas (municipalities of Fortaleza - F, Barbalha - J and Lavras da Mangabeira - A). The second group had many subdivisions: the first in Minas Gerais state: areas B (Abaeté) and $\mathrm{K}$ (Vale do Jequitinhonha), which had the greatest floristic similarity among all analyzed areas (0.4646). The second subgroup (with the second largest similarity value) represents areas D and $\mathrm{H}$ (Distrito Federal and Western Bahia state), which are about $650 \mathrm{Km}$ distant from each other.

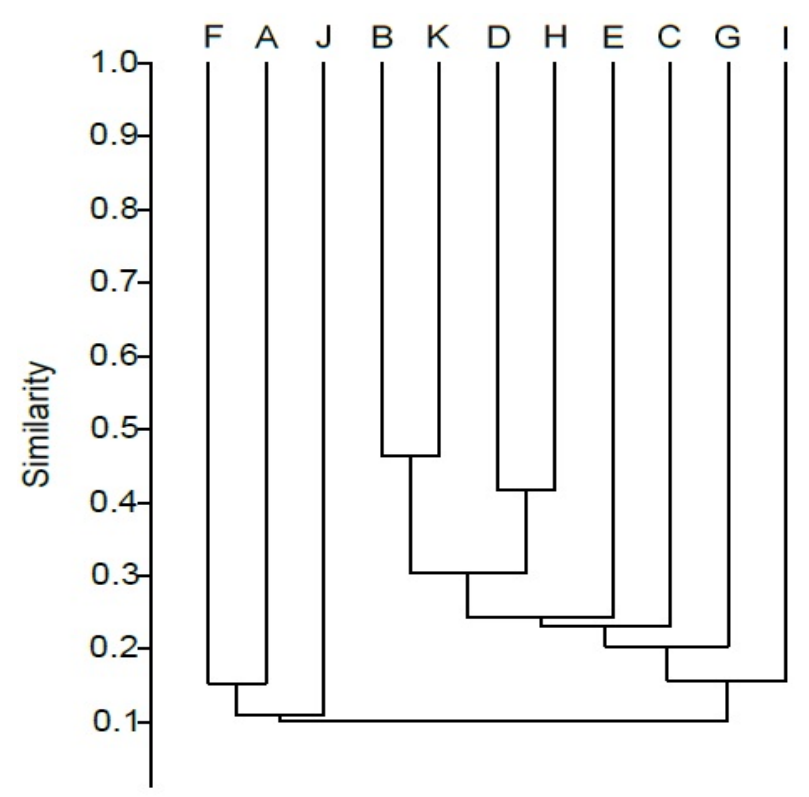

Figure 5. Dendrogram generated by the Jaccard similarity index between 11 areas of Cerrado in eight Brazilian states

The observed heterogeneity and low indexes in the floristic similarity comparison are important factors to be considered in the gathering for means of conservation of this relevant and threatened richness of biodiversity; in the present case expressed by a reminiscent of a larger Cerrado area that covered the region in the past. It still exists today within the Caatinga of the Brazilian Crystalline Shield, in the semiarid area, at mid-elevation hills like Serra do Boqueirão, but it is fading because conservation efforts are neglected, and because of the planetary climate change occurring since the last Ice Age.

\section{CONCLUSIONS}

The phytosociology and floristic diversity results point to the existence of a Cerrado sensu stricto located inside the Caatinga of the Brazilian Crystalline Shield, in the semi-arid region of Northeastern Brazil, Lavras da Mangabeira municipality. This study is the first to observe the vegetation structure of the area.

Typical Cerrado species like Qualea parviflora and Callisthene fasciculata (both Vochysiaceae) and Anacardium occidentale (Anacardiaceae) had the highest IVI values of the analyzed fragment, emphasizing structural and floristic bonds of the area, especially with the coastal savanna of Ceará state, as well as with other areas of marginal and central Cerrado areas.

The values of diversity, equability and concentration indexes suggest a high species richness (high alpha diversity), high uniformity of population size and low species concentration. The beta diversity is considered high by the heterogeneity in comparison with Cerrado areas in other regions of the country. 


\section{ACKNOWLEDGEMENTS}

The authors thank Coordenação de Aperfeiçoamento de Pessoal de Nível Superior (CAPES); Fundação Cearense de Apoio ao Desenvolvimento Científico e Tecnológico (FUNCAP); Conselho Nacional de Desenvolvimento Científico e Tecnológico (CNPq), Embrapa Semiárido and Universidade Regional do Cariri (URCA).

\section{REFERENCES}

Ab'Saber, A. N. (1963). Contribuição a Geomorfologia dos Cerrados. In M. G. Ferri (Ed.), Simpósio sobre o cerrado (pp. 117-124). São Paulo: Editora da Universidade de são Paulo.

Angiosperm Phylogeny Group - APG (2016). An update of the Angiosperm Phylogeny Group classification for the orders and families of flowering plants: APG IV. Botanical Journal of the Linnean Society, 181(1), 1-20. http://dx.doi.org/10.1111/boj.12385.

Assunção, S. L., \& Felfili, J. M. (2004). Fitossociologia de um fragmento de cerrado sensu stricto na APA do Paranoá, DF, Brasil. Acta Botanica Brasilica, 18(4), 903-909. http://dx.doi.org/10.1590/S010233062004000400021.

Bezerra, J. S. (2018). Florística e síndromes de dispersão de uma área de Cerrado disjunto na chapada do Araripe, Nordeste do Brasil (Dissertação de mestrado). Universidade Regional do Cariri, Crato.

Brasil. Ministério do Meio Ambiente. (2016). Ceará: inventário florestal nacional: principais resultados. Brasília: Serviço Florestal Brasileiro.

Brower, J. E., Zar, J. H., \& von Ende, C. N. (1998). Field and laboratory methods for general ecology (273 p.). New York: WCB/McGraw-Hill.

Calgaro, H. F., Cambuim, J., Silva, A. M., Alves, M. C., Buzetti, S., Moraes, M. A., Carvalho, S. L., Miranda, L. P. M., \& Moraes, M. L. T. (2015). Distribuição natural de espécies arbóreas em áreas com diferentes níveis de antropização. Atributos físicos do solo. Revista Cultura Agronômica, 24(3), 327-344. http://dx.doi.org/10.32929/2446-8355.2015v24n3p327-344.

Calixto Júnior, J. T., \& Drumond, M. A. (2011). Estrutura fitossociológica de um fragmento de caatinga sensu stricto, 30 anos após corte raso, Petrolina-PE, Brasil. Revista Caatinga, 24(2), 67-74.

Calixto Júnior, J. T., \& Drumond, M. A. (2014). Estudo comparativo da estrutura fitossociológica de dois fragmentos de Caatinga em níveis diferentes de conservação. Pesquisa Florestal Brasileira, 34(80), 1 11. http://dx.doi.org/10.4336/2014.pfb.34.80.670.

Carneiro Filho, A. (1993). Cerrados Amazônicos: fosséis vivos? Algumas reflexões. Ver. Inst. Geol, 14, 6368.

Castro, A. A. J. F., Martins, F. R., \& Fernandes, A. G. (1998). The woody flora of the cerrado vegetation in the state of Piauí, northeastern Brazil. Edinburgh Journal of Botany, Edinburgh, 55(3), 455-472. http://dx.doi.org/10.1017/S0960428600003292.

Cerqueira, C. L., Lisboa, G. S., Stepka, T. F., França, L. C. J., Fonseca, N. C., Abreu, Y. K. L., \& Santos, J. C. (2017). Florística, Fitossociologia e Distribuição Diamétrica em um Remanescente de Cerrado sensu stricto, Brasil. Revista Espacios, 38(23), 13-27.

Cole, M. M. (1986). The Savannas. Biogeography and Geobotany. London, UK: Academic Press, Harcourt Brace Javanovich Publishers.

Cordeiro, L. (2002). Fixação de nitrogênio em leguminosas ocorrentes no Cerrado. In: Klein, A.L. (Org.), Eugen warming e o cerrado brasileiro: um século depois (p.131-145). São Paulo: UNESP.

Costa, I. R., \& Araújo, F. S. (2007). Organização comunitária de um encrave de cerrado sensu stricto no bioma Caatinga chapada do Araripe, Barbalha, Ceará. Acta Botanica Brasílica, 21(2), 281-29. http://dx.doi.org/10.1590/S0102-33062007000200004.

Felfili, J. M., \& Rezende, R. P. (2003). Conceitos e Métodos em Fitossociologia (68 p.). Brasília: Universidade de Brasília, Departamento de Engenharia Florestal.

Felfili, J. M., Nogueira, P. E., Silva Júnior, M. C., Marimon, B. S., \& Delitti, W. B. C. (2002). Composição florística do cerrado sentido restrito no município de Água Boa, MT. Acta Botanica Brasílica, 16(1), 103-112. http://dx.doi.org/10.1590/S0102-33062002000100012.

Felfili, J. M., Silva Junior, M. C., Rezende, A. V., Nogueira, P. E., Walter, B. M. T., Silva, M. A., \& Encinas, J. I. (1997). Comparação florística e fitossociológica do cerrado nas chapadas Pratinha e dos Veadeiros. In L. Leite \& C.H. Saito (Eds.), Contribuição ao conhecimento ecológico do cerrado (p. 6-11). Brasília: Ed. Universidade de Brasília. 
Ferraz, R. C., Mello, A. A., Ferreira, R. A., \& Nacimento-Prada, A. P. (2013). Levantamento Fitossociológico em área de caatinga no monumento natural Grota do Angico, Sergipe, Brasil. Revista Caatinga, Mossoró, 26(3), 89-98.

Ferreira Júnior, E. V., Soares, T. S., Costa, M. F. F., \& Silva, V. S. M. (2008). Composição, diversidade e similaridade florística de uma floresta tropical semidecídua submontana em Marcelândia - MT, Brasil. Revista Acta Botanica Brasilica, 38(4), 673-680.

Ferreira, R. Q. S., Camargo, M. O., Souza, P. B., \& Andrade, V. C. L. (2015). Fitossociologia e estrutura diamétrica de um cerrado sensu stricto, Gurupi - TO. Revista Verde de Agroecologia e Desenvolvimento Sustentável, 10(1), 229-235. http://dx.doi.org/10.18378/rvads.v10i1.2996.

Fidelis, A. T., \& Godoy, S. A. P. (2003). Estrutura de um Cerrado stricto sensu na gleba Cerrado Pé-degigante, Santa Rita do Passa Quatro, SP. Acta Botanica Brasílica, 17(4), 531-539. http://dx.doi.org/10.1590/S0102-33062003000400006.

Figueiredo, M. A., \& Fernandes, A. (1987). Encraves de Cerrado no interior do Ceará. Ciência Agronômica, $18(2), 103-106$.

Figueiredo, M. A. (1997). A cobertura vegetal do Ceará (Unidades Fitoecológicas). In Atlas do Ceará (pp. 28-29). Ceará, Fortaleza: Edições IPLANCE.

Finger, Z., \& Finger, F. A. (2015). Fitossociologia em comunidades arbóreas remanescentes de Cerrado Sensu stricto no Brasil central. Revista Floresta, 45(4), 769-780. http://dx.doi.org/10.5380/rf.v45i4.30860.

Freire, L. M. (2007). Paisagens de exceção: problemas ambientais no Município de Mulungu (Dissertação de mestrado). Centro de Ciências e Tecnologias, Universidade Estadual do Ceará, Serra de Baturité, Ceará.

Fundação Cearense de Meteorologia e Recursos Hídricos - FUNCEME. (2019). Calendário Chuvoso. Recuperado em 25 de março de 2019, de http://www.funceme.br/

Gentry, A. H., Herrera-Mac Brybe, O., Huber, O., Nelson, B. W., \& Villamil, C. B. (1997). Regional overview: South America. In V.H. Heiwood \& S. D. Davis (Eds.), Centre of plant diversity (pp. 269-307). Cambridge: WWF/IUCN,.

Gottsberger, G., \& Silberbauer-Gottsberger, I. (2006). Life in the Cerrado: a South American Tropical Seasonal Vegetation (V. II. Pollination and seed dispersal) (385 p.). Ulm: Reta Verlag.

Hammer, O., Harper, D. A. T., \& Ryan, P. D. (2011). PAST: Paleontological Statistic software package for education and data analysis. Palaeontologia Electronica, 4(1), 1-9.

Haridasan, M. (2000). Nutrição mineral de plantas nativas do cerrado. Revista Brasileira de Fisiologia Vegetal, 12(1), 54-64.

Imaña-Encinas, J., Macedo, L. A., \& Paula, J. E. (2007). Florística e Fitossociologia de um trecho de floresta estacional semidecidual na área do Ecomuseu do Cerrado em Pirenópolis-Goiás. Cerne, 13(3), 308320.

Institudo Nacional de Pesquisas Espaciais - INPE. (2019). Previsão de tempo: Lavras da Mangabeira - CE. Recuperado em 24 de abril de 2019, de https://tempo.cptec.inpe.br/ce/lavras-da-mangabeira.

Instituto Brasileiro de Geografia e Estatística - IBGE (2004). Biomas. Recuperado em 06 de abril de 2021, de https://geoftp.ibge.gov.br/informacoes_ambientais/estudos_ambientais/biomas/mapas/biomas_50 00mil.pdf.

Instituto Brasileiro de Geografia e Estatística - IBGE (2010). Lavras da Mangabeira - CE. Recuperado em 25 de agosto de 2018, de https://cidades.ibge.gov.br/brasil/ce/lavras-da-mangabeira/historico.

Kent, M., \& Coker, P. (1992). Vegetation Description and Analysis: A Practical Approach (pp. 167-169). New York: John Wiley and Sons.

Klink, C. A., \& Machado, R. B. (2005). A conservação do cerrado brasileiro. Megadiversidade, São Paulo, 1(1), 147-155.

Lemos, H. L., Pinto, J. R. R., Mews, H. A., \& Lenza, E. (2013). Structure and floristic relationships between Cerrado sensu stricto sites on two types of substrate in northern Cerrado, Brazil. Biota Neotropica, São Paulo, 13(4), 121-132. http://dx.doi.org/10.1590/S1676-06032013000400013.

Lopes, A. S., \& Cox, F. R. (1977). A survey of the fertility status of surface soils under 'cerrado' vegetation in Brazil. Soil Science Society of America Journal, 41(4), 741-747. http://dx.doi.org/10.2136/sssaj1977.03615995004100040026x.

Magurran, A. E. (1988). Ecological Diversity and its measurement (179 p.). Princeton: Newjersey. http://dx.doi.org/10.1007/978-94-015-7358-0. 
Marangon, L. C., Feliciano, A. L. P., Brandão, C. F. L. S., \& Alves Junior, F. T. (2008). Relações florísticas, estrutura diamétrica e hipsométrica de um fragmento de floresta estacional semidecidual em Viçosa (MG). Revista Floresta, 38(4), 699-709.

Matos, M. Q., \& Felfili, J. M. (2010). Florística, fitossociologia e diversidade da vegetação arbórea nas matas de galeria do Parque Nacional de Sete Cidades (PNSC), Piauí, Brasil. Acta Botanica Brasílica, 24(2), 483-496. http://dx.doi.org/10.1590/S0102-33062010000200019.

Medeiros, M. B., Walter, B. M. T., \& Silva, G. P. (2008). Fitossociologia do cerrado stricto sensu no município de Carolina, MA, Brasil. Cerne, 14, 285-294.

Mendonça, R. C., Felfili, J. M., Walter, B. M. T., Silva Júnior, M. C., Rezende, A. V., Filgueiras, T. S., Nogueira, P. E., \& Fagg, C. W. (2008). Flora Vascular do Bioma Cerrado. In S. M. Sato, S. P. Almeida, \& J. F. Ribeiro (Eds.), Cerrado: ecologia e flora. Brasília: Embrapa Informação Tecnológica, p.421-1279.

Mendonça, R. C., Felfili, J. M., Walter, B. M. T., Silva-Júnior, M. C., Rezende, A. V., Filgueiras, T. S., \& Nogueira, P. E. N. (1998). Flora lenhosa do bioma cerrado. In S. M. Sato \& S. P. Almeida (Eds.), Cerrado: ambiente e flora (pp. 289-556). Planaltina: Embrapa Cerrados.

Mews, H. A., Marimon, B. S., Maracahipes, L., Franczak, D. D., \& Marimon-Junior, B. H. (2011). Dinâmica da comunidade lenhosa de um Cerrado Típico na região Nordeste do Estado de Mato Grosso, Brasil. Biota Neotropica, 11(1), 73-82. http://dx.doi.org/10.1590/S1676-06032011000100007.

Missouri Botanical Garden - MOBOT W3MOST (2019). Recuperado em 16 de janeiro de 2019, de http://www.mobot.mobot.org/W3T/Search/vast.html.

Moro, M. F., Castro, A. S. F., \& Araújo, F. S. (2011). Composição florística e estrutura de um fragmento de vegetação savânica sobre os tabuleiros pré-litorâneos na zona urbana de Fortaleza, Ceará. Rodriguésia, 62(2), 407-423. http://dx.doi.org/10.1590/2175-7860201162214.

Moro, M. F., Macedo, M. F., Moura-Fé, M. M., Castro, A. S. F., \& Costa, R. C. (2015). Vegetação, unidades fitoecológicas e diversidade paisagística do estado do Ceará. Rodriguésia, 66(3), 717-743. http://dx.doi.org/10.1590/2175-7860201566305.

Mueller-Dumbois, D., Ellenberg, H. (1974). Aims and methods of Vegetation Ecology (525 p.). New York: J. Wiley \& Sons.

Nepomuceno, I. V. (2016). Flora de um enclave de cerrado no município de Granja, CE - dados preliminares. Anais do I Congresso Internacional da Diversidade do Semiarido, Campina Grande, PB: Realize Editora.

Neri, A. V., Meira-Neto, J. A. A., Silva, A. F., Martins, S. V., \& Batista, M. L. (2007). Análise da estrutura de uma comunidade lenhosa em área de cerrado sensu stricto no município de Senador Modestino Gonçalves, Norte de Minas Gerais, Brasil. Revista Árvore, 31(1), 123-134. http://dx.doi.org/10.1590/S0100-67622007000100014.

Oestreich-Filho, E. (2014). Fitossociologia, diversidade e similaridade entre fragmentos de cerrado stricto sensu sobre neossolos quartzarênicos órticos, nos municípios de Cuiabá e Chapada dos Guimarães, estado de Mato Grosso, Brasil (Dissertação de mestrado). Universidade Federal de Mato Grosso, Cuiabá, MT.

Oliveira, C. P., Francelino, M. R., Cysneiros, V. C., Andrade, F. C., \& Booth, M. C. (2015). Composição florística e estrutura de um Cerrado Sensu stricto no Oeste da Bahia. Cerne, 21(4), 545-552. http://dx.doi.org/10.1590/01047760201521041722.

Oliveira, P. E. A. M. (2008). Fenologia e Biologia Reprodutiva das Espécies de Cerrado. In S. M. Sano, S. P. Almeida \& J. F. Ribeiro (Eds). Cerrado: ecologia e flora (pp. 273-290). Planaltina: EMBRAPA-CPAC.

Oliveira-Filho, A. T. (2006). Catálogo das árvores nativas de Minas Gerais: mapeamento e inventário da flora nativa e dos reflorestamentos de Minas Gerais. Lavras: Editora UFLA.

Pereira, B. A. S., Venturoli, F., \& Carvalho, F. A. (2011). Florestas Estacionais no Cerrado: Uma Visão Geral. Pesquisa Agropecuária Tropical, 41(3), 446-455. http://dx.doi.org/10.5216/pat.v41i3.12666.

Pivello, V. R., \& Coutinho, L. M. (1996). A qualitative successional model to asssist in the management of Brazilian cerrados. Forest Ecology and Management, 87(1-3), 127-138. http://dx.doi.org/10.1016/S0378-1127(96)03829-7.

Ratter, J., Bridgewater, S., \& Ribeiro, J. F. (2003). Analysis of the floristic composition of the Brazilian Cerrado vegetation III: comparison of the woody vegetation of 376 areas. Edinburgh Journal of Botany, 60(1), 57-109. http://dx.doi.org/10.1017/S0960428603000064.

Ribeiro, J. F., \& Walter, B. M. T. (1998). Fitofisionomias do bioma Cerrado: os biomas do Brasil. In S. M. Sano \& S. P. Almeida. Cerrado: ambiente e flora (p. 89-116). Planaltina: EMBRAPA. 
Ribeiro, J. F., \& Walter, B. M. T. (2008). As principais fitofisionomias do Bioma Cerrado. In S. M. Sano, S. P. Almeida \&J. F. Ribeiro, eds. Cerrado: ecologia e flora (pp. 151-212). Planaltina: Embrapa Cerrados.

Rodal, M. J. N. (1992). Fitossociologia da vegetação arbustivo-arbórea em quatro áreas de caatinga em Pernambuco (Tese de Doutorado). Universidade Estadual de Campinas, Campinas. 198 p.

SAEG (2007). Sistema para Análises Estatísticas, Versão 9.1. Viçosa: Fundação Arthur Bernardes, UFV.

Sampaio, A. C. F., Bianchin, J. E., Santos, P. M., Ariati, V., \& Santos, L. M. (2018). Fitossociologia do Cerrado sensu stricto na bacia do Rio Parnaíba no nordeste brasileiro. Advances in Forestry Science, 5(2), 299-307.

Santos, L. S., Cabral, C. J., \& Silva, H. P. B. (2015). Mancha de Cerrado associada à teoria dos refúgios no Agreste Pernambucano. Revista Ceres, 1(2), 169-175.

Sneath, P. H. A., \& Sokal, R. R. (1973). Numerical taxonomy: the principles and practice of numerical classification (573 p.). San Francisco: W. H. Freeman and Company.

Saporetti-Junior, A. W., Meira-Neto, J. A. A., \& Almado, R. P. (2003). Fitossociologia de cerrado sensu stricto no município de Abaeté-MG. Revista Árvore, 27(3), 413-419. http://dx.doi.org/10.1590/S010067622003000300020.

Sheperd, G. J. (2010). FITOPAC 2: manual do usuário (91 p.). Campinas: Unicamp.

Silva-Neto, V. L., Oliveira, A. L., Ferreira, R. Q. S., Souza, P. B., \& Viola, M. B. (2016). Fitossociologia e distribuição diamétrica em uma área de Cerrado sensu stricto, Dueré-TO. Revista de Ciências Ambientais, 10(1), 92-106.

Silveira, E. P. (2010). Florística e estrutura da vegetação de Cerrado sensu stricto em Terra Indígena no noroeste do estado de Mato Grosso (Dissertação de mestrado). Universidade Federal de Mato Grosso, Cuiabá, MT. 61 p.

Tavares, M. E. F. (2017). Estrutura fitossociológica de um fragmento de Cerrado sensu stricto no sul do Tocantins (Dissertação de mestrado). Universidade Federal do Tocantins, Gurupi, TO.

Winterhalder, K. (1996). Environmental degradation and rehabilitation of the landscape around Sudbury, a major mining and smelting area. Environmental Reviews, 4(3), 185-224. http://dx.doi.org/10.1139/a96-011.

Xavier, K. R. F. (2009). Análise florística e fitossociológica em dois fragmentos de floresta serrana no município de Dona Inês, Paraíba (Dissertação de mestrado). Universidade Federal da Paraíba, Areia, PB.

Authors' contributions: JTCJ: funding acquisition, metodology, investigation, project administration, supervision; JCM: conceptualization, data curation, formal analysis, methodology, writing - original draft; MANL: conceptualization, data curation, writing; GVC: conceptualization, software, investigation; BLMG: conceptualization, software, investigation; ESSTB: investigation, methodology; LMB: data curation, formal analysis, visualization; MAD: resources, methodology, writing - review and editing; ACAMM: validation, visualization; LSGR: formal analysis, software; MAPS: validation, visualization, resources; LSC: methodology, software. 